\title{
“University Challenges”: Addressing Transition and Retention through Games-Based Learning
}

\author{
Gerodetti, Natalia ${ }^{a}$; Nixon, Darren ${ }^{a}$
}

${ }^{\mathrm{a}}$ School of Social Sciences, Leeds Beckett University, UK

\begin{abstract}
In the changing UK Higher Education landscape, addressing student retention and attrition rates is of increasing importance. In this paper, after first reviewing literature on the factors influencing student retention and attrition, we explore how the transition to university life for first-year students might be addressed through a games-based learning approach. We explore the benefits of facilitating 'students as (games) producers' and incorporating 'student intelligence' into university teaching and learning practices before presenting 'University Challenges', a new-traditional board game produced through a collaborative staff-student project between sociology students and lecturers at Leeds Beckett University. Drawing on data from student evaluations from three different academic courses, we reflect on how playing 'University Challenges' can help first-year students develop the kinds of skills and knowledge basis that contributes to a better experience of the transition and acculturation into university life in all of its facets.
\end{abstract}

Keywords: games-based learning; retention; attrition; students as producers; induction. 


\section{Introduction}

Within the changing UK Higher Education landscape students' successful transition into university, measured by their ability to progress into the second year of study, has become a key performance indicator. Retention and attrition are significant issues for universities and higher education funding councils and increasing attention has been given to how to improve student retention and to explore the causes of attrition (Wilcox et al., 2005; O'Keefe, 2013; HEFCE, 2013). Student attrition costs universities in terms of lost revenue whilst also not reflecting well upon the institution (Longden, 2009). Overall, noncontinuation rates for undergraduate students vary according to discipline and a range of factors both endogenous and exogenous to the university itself are important. Rates have slightly risen to $6 \%$ in the latest figures produced for 2013/14 entry (HESA, 2016) but in our disciplinary area - sociology - non-continuation rates are higher reaching with $10.7 \%$ in the 2012/13 entry (HEFCE, n.d.), although they have been slightly decreasing recently. For a variety of reasons, student dis-continuation is slightly above sector average in our institution and student retention is therefore an issue for course management. However, our focus here is less with the institutional frame and more with the wellbeing and experiences of our students. Acculturation to university life and expectations is a key concern for students wanting to succeed on their course and avoid the expenses associated with dropping-out or repeating a year. Thus, this paper charts how we have attempted to collaboratively address these concerns through a staff-student project exploring how the transition to university life might be smoothened through game-based learning, resulting in an extended induction or 'long thin induction'.

\section{Attrition, Retention and the First-year Transition}

Experiences in the early weeks of university life are important in influencing students' decisions to withdraw from their course (Wilcox et al., 2005). It is widely agreed in the literature that the transition to university life presents both opportunities and a range of significant challenges for first-year students. They are required to negotiate a variety of new experiences in order to 'fit in' with both the academic and social aspects of university life (Wilcox et al., 2005). New students have to deal with factors such as relocation, separation from family and friends, living with strangers and adjustment to new expectations around independent learning and academic life more generally. These challenges substantially impact upon their sense of identity and belonging and can generate feelings of disorientation (Briggs et al., 2012), or isolation and loneliness (Scanlon et al., 2007). In this context establishing a 'new' identity and a sense of belonging through relationships with peers, and to a lesser extent staff, appear key (Wilcox et al., 2005; Scanlon et al., 2007).

In their small-scale qualitative research on first-years who withdrew from or stayed on their social science course, Wilcox et al. (2005) argue that retention issues are complex and 
multifaceted. Amongst leavers the main difficulties centered around social issues (making friends, feeling lonely and lacking emotional support), academic issues (course fit, expectations mismatch, independent learning) and material issues (accommodation, finance, location). In particular they emphasize the importance of social support and networks as $3 / 4$ of leavers mention difficulties with making friends. As Yorke and Longden (2007) argue in their review of research around retention, simply making friends is crucial to a successful transition into higher education.

In the context of wide-ranging changes to $\mathrm{HE}$, and particularly an increasingly diverse student body, attention has focused on how HE institutions might better understand student transitions and provide more appropriate student support. Here the induction period has been identified as important. O'Keefe (2013) argues that creating a sense of belonging by course tutors is crucial whilst, at the same time, avoiding information overload in the induction and the first weeks of study (Hamshire \& Cullen 2010) which students can perceive to be bewildering. Rather, using this period as a chance to build and establish positive peer friendships, coaching and mentoring relationships amongst students may prove particularly fruitful (Briggs et al. 2012).

In terms of creating a more positive transition, Longden (2009) has argued that institutions are recognizing the value of a 'longer and thinner' induction experience that starts early and lasts longer than one week. This de-emphasizes the bewildering first week, and provides more opportunity for new students to assimilate and make sense of the information provided. Furthermore a range of activities can (with less emphasis on alcohol, which could alienate some students) help students and staff to socialize and to engage in and belong to the HE community at their institution. Related to that, Kift et al. (2010) propose a 'transition pedagogy' that encourages students to become members of a community of learners and recognizes that first-year students have particular needs based on the transition experience. This approach likewise sees transition not as an introductory event, but as a year long process with curriculum as a thread to which other aspects of transition must be added (Bowles et al., 2014). 


\section{Students as Producers of Games}

We have discussed elsewhere some of the key tenets of the 'students as producers' discourse (Gerodetti and Nixon, 2014). One of its foundational principles is to explore ways in which 'student intelligence' can be incorporated into teaching and learning practices 'through collaboration with academics on research projects of real intellectual value' (Neary, 2012: 2). We have successfully applied the principles of this discourse in a previous collaborative project with students who created games that can be used to teach research methods and ethics (Gerodetti and Nixon, 2014). A key observation from our game-design workshops and watching our students play the games with other students during testing was the positive social relationships that were built amongst students from different year groups both making and playing the game. Older students reveled in coaching and mentoring less experienced students, who appeared to feel reassured by the advice they received.

Given the characteristics of first-year transition experiences discussed above and the positive social and interactive attributes associated with new-traditional games (Gerodetti and Nixon, 2014), a 'transition game' or a game that can be played during a long induction process that addresses issues new students face would appear to offer a range of potential benefits. These include providing a context for socializing and building relationships with new course mates, developing a reassuring awareness that others share their fears, information sharing and collective and collaborative problem-solving. In designing games, students as game producers is a useful approach to address transition issues because they have recent experiences and expert knowledge of making, and are still in the process of making, such transitions. Strikingly, students highlighted that the game could address both academic and non-academic issues.

Unlike another project (located in Health Care) with an all-lecturer design team (see Hamshire and Forsyth, 2014), we centralized our students' experiences giving them the task to design a game which would not only introduce first-year students to common concerns and problems but also encourage them to collaboratively construct solutions to dilemmas posed in the game. The game, as it stands, was designed by sociology students (from different year groups) with no background in game design. The learning objectives were defined collectively as; to develop an awareness of issues commonly encountered by firstyear students; to develop skills and knowledge to solve such issues; and to develop a student community based on shared values. This final objective shaped the decision to develop a new traditional game which could be played in groups. In building collective knowledge and addressing common students issues, a student community with shared values and shared knowledge may be fostered through playing the game. These learning objectives were achieved through the content of the game and collaborative play. 


\section{The Game}

'University Challenges' is an interactive, competitive and collaborative board game (Figure 1) in which students attempt to accumulate credits by moving around a board and be the first to 'pass-progress' (to the second year) to thereby win. The game is built on a games-based learning paradigm which, in this case, is not about using 'serious games' to provide learning opportunities for course content. Instead the game aims to provide learning opportunities around the transitional aspects of becoming a learner in a contemporary Higher Education system. The game therefore mirrors some of the structuring aspects of first year student life requiring each group/team to

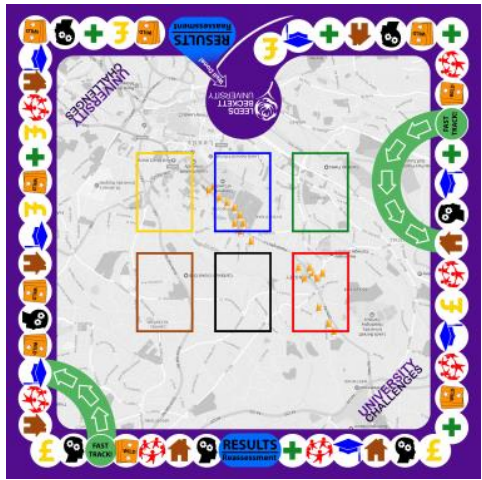

Figure 1: The University Challenges Board Game complete six modules of the course structure in order to reach the goal 'pass-progress'. This refers to the exam board terminology used at our university to indicate a student's entitlement to proceed into the second year of study.

Equally significant, the game allows students to become accustomed to aspects of student life through a mixture of luck and problem solving components, which intend to increase their knowledge and strengthen collaboration and social connections amongst first-year students. Our peer-competitive board game introduces students to the specificities of becoming a student and is organized around six key areas of student life identified by student game designers, namely: having to manage one's own finances, dealing with accommodation issues, establishing new social connections and maintaining old ones, social and peer aspects of being a student, knowledge about wider health and safety aspects and, finally, academic conventions and frameworks as they affect students.

The game is played in 2-3 teams with 2-4 players per team. Teams throw a dice in order to move around the board with the aim of gathering enough credit points to 'pass-progress' at the end of the year/game. Teams earn credit points through their response to a card that they are presented with upon landing on one of the 6 topic fields on the board. The cards are a range of luck cards, multiple choice answer cards and dilemma/debate cards. The latter are designed to create debate and then consensus finding within the group. Games can be facilitated by a student (mentor) who awards credit points based on the quality of answers to the dilemma/debate at hand and is also able to add their own advice/experience where relevant. Key elements within the game thus include luck, information provision (i.e. university policies and services) and the development of team-working, negotiating and 
problem-solving skills. Notably, five of the six categories within the game address nonacademic areas of student life such as 'Health \& Safety', 'Accommodation', 'Personal', 'Finance', 'Social \& General Knowledge'. Only one category pertains to 'Academic' issues, which strongly reflects our student designers' agenda. Interestingly, our student game designers' agenda is supported by the literature on the issues influencing retention discussed above. Significantly, the focus on empowering students as (game) producers and in being student-led in game-design is different to Hamshire and Forsyth's (2014) tutor-led game, which over-emphasized academic issues.

\section{Evaluating 'University Challenges'}

The game has undergone a testing phase as well as a full evaluation of the second iteration which was played, in different ways, by first-year students from sociology, politics and games design. On the sociology course the game was played within the first seminar of a module and facilitated by second year students who had been involved in the games development process. Sociology students $(\mathrm{N}=76)$ overwhelmingly provided good to excellent feedback on the game, including some qualitative comments that they really liked having the opportunity to engage with second-year students in the course of playing the game. Thus a strong mentoring aspect accompanied the use of the game in sociology. By contrast, the politics team used the games within several small group tutorials and used the game's questions and dilemmas explicitly as a prompt for further discussion. This resulted in the game not being completed within the 50 minutes session. Feedback from the tutor indicated that both the tutor and the students liked the idea and the questions to discuss issues in more detail, but were frustrated with not completing the game. No evaluations were returned from the students. On the games design course 16 students played the game in a self self-administered way within a module that examines games design and game mechanics across a variety of currently available games including board games. Game design students, mostly male, were rather less impressed by the former look and design but were also frustrated by the instructions which they found cumbersome.

The overall evaluation of the game points to it generally fulfilling the learning objectives. For example, $60.9 \%$ of students thought the game was either 'quite' or 'very' useful in helping familiarize themselves with their new university environment (see table 1). More significantly, $70.6 \%$ thought that it was 'quite' or 'very' useful in learning about student issues and $70.8 \%$ thought it was 'quite' or 'very' useful in getting to know other students two of the key learning outcomes formulated at the beginning of the development process. However, the game was less successful in relation to the third learning objective as only $53.2 \%$ of students reported that the game was 'quite' or 'very' useful in helping find diverse soultions to various problems. 


\begin{tabular}{|l|c|c|c|c|}
\hline Learning Outcomes & $\begin{array}{l}\text { Not } \\
\text { useful }\end{array}$ & $\begin{array}{l}\text { A little } \\
\text { useful }\end{array}$ & $\begin{array}{l}\text { Quite } \\
\text { useful }\end{array}$ & $\begin{array}{l}\text { Very } \\
\text { useful }\end{array}$ \\
\hline $\begin{array}{l}\text { How useful did you find the game in } \\
\text { familiarising yourself with Leeds } \\
\text { Beckett University? }\end{array}$ & $\mathrm{N}=10$ & $\mathrm{~N}=26$ & $\mathrm{~N}=39$ & $\mathrm{~N}=17$ \\
\hline $\begin{array}{l}\text { How useful was the game in } \\
\text { familiarising yourself with student } \\
\text { issues? }\end{array}$ & $\mathrm{N}=11$ & $\mathrm{~N}=16$ & $\mathrm{~N}=45$ & $\mathrm{~N}=20$ \\
\hline $\begin{array}{l}\text { How useful was the game in } \\
\text { becoming more familiar with diverse } \\
\text { solutions? }\end{array}$ & $\mathrm{N}=11$ & $\mathrm{~N}=32$ & $\mathrm{~N}=36$ & $\mathrm{~N}=13$ \\
\hline $\begin{array}{l}\text { How useful is the game in getting to } \\
\text { know other students? }\end{array}$ & $\mathrm{N}=6$ & $\mathrm{~N}=20$ & $\mathrm{~N}=44$ & $\mathrm{~N}=21$ \\
\hline
\end{tabular}

Table 1. Student Evaluation 2016-17 from first year students from

\section{BA (Hons) Games Design ( $\mathrm{N}=16)$ and BA (Hons) Sociology $(\mathrm{N}=76)$}

One of the weaknesses of the first iteration of the game was its slow pace and so the second iteration, when played as a competitive game, is designed to take 35-50 minutes to play, thereby fitting into conventional times slots often used in teaching. Students were asked to rate the game on a scale of 1-10 (10 being highest). 64.1\% scored the game beteween 7-10, $22.8 \%$ between $4-6$ and $13.0 \%$ rated the game 1-3 (all but one of the games design students for which there are a number of reasons).

\section{Conclusion}

Transition into HE is not just marred with problems and it is worth remembering that most students transition 'successfully'. Students are an increasingly diverse body that experience transitions in different ways and with differential access to resources and social and cultural capital. Research on first-year transitions and retention suggests the relationship is complex and multi-faceted. Nonetheless it is possible to identify common issues that cut across both 'stayers' and 'leavers' experiences, but perhaps particularly affect 'leavers'; these are namely 'social' aspects as well as 'academic' and 'financial' ones. Our student gamedesigners built their own tacit knowledge and experience of transitioning into the mechanics of the game. Along with gaining deeper knowledge of 'student life', it is our contention that the game also encourages positive social interaction amongst first-year students (and peers in older cohorts), ultimately helping the development of the peer support and friendship networks that appear so important for the successful transition to university life. 


\section{References}

Bowles, A., Fisher, R., McPhail, R., Rosenstreich, D. \& Dobson, A. (2014). Staying the distance: Students' perceptions of enablers of transition to higher education. Higher Education Research and Development, 33(2), 212-225.

Briggs, A.R.J., Clark, J., \& Hall, I. (2012). Building bridges: Understanding student transition to university. Quality in Higher Education, 18(1), 3-21.

Gerodetti, N., \& Nixon, D. (2014) Proceedings from $8^{\text {th }}$ ECGBL: Students as producers: Designing games to teach social science research methods and ethics. Reading: Dechema.

HESA (2016). UK performance Indicators 2014/15: Non-continuation rates, Available at: https://www.hesa.ac.uk/data-and-analysis/performance-indicators/non-continuation.

HEFCE (n.d.) Non-continuation rates: Trends and profiles. Retrieved from: http://www.hefce.ac.uk/analysis/ncr/ds/.

Hamshire, C., \& Cullen, R. (2010). Developing a spiraling induction programme: A blended approach. In K. Anagnostopoulou \& D. Parmer (Eds), Supporting first year Student experience through the use of learning technologies (pp. 32-34). Middlesex: HEA.

Hamshire, C., \& Forsyth, R. (2014). Contexts and concepts: Crafty ways to consider challenging topics. In A. Moseley \& N. Whitton (Eds). New traditional games for learning: a case book (pp.161-175). London: Routledge.

Jones, R. (2009). Student Retention and Success. Retrieved from: HEA http://evidencenet.pbworks.com/w/page/19383519/Student\%20Retention\%20and\%20S uccess.

Kift, S., Nelson, K. \& Clarke, J. (2010). Transition pedagogy: A third-generation approach to FYE: A case study of policy and practice for the higher education sector. International Journal of the First Year in Higher Education, 1(1): 1-20.

Longden, R. (2009). Student retention and success, Retrieved from: http://evidencenet.pbworks.com/w/page/19383519/Student\%20Retention\%20and\%20S uccess\#Inductionandtransitionsupport

Neary, M. (2012). Teaching politically: Policy, pedagogy and the new european university. Journal for Critical Education Policy Studies, 10(2), 233-257.

O'Keefe, P. (2013). A sense of belonging: Improving student retention. College Student Journal, 47(4), 605-613.

Scanlon, L., Rowling, L., \& Weber, Z. (2007). 'You don't have like an identity...you are just lost in a crowd': Forming a student identity in the first-year transition to university. Journal of Youth Studies, 10(2), 223-241.

Wilcox, P., Winn, S., \& Fyvie-Gauld, M. (2005) 'It was nothing to do with the university, it was just the people': the role of social support in the first-year experience of higher education. Studies in Higher Education, 30(6), 707-722.

Yorke, M., \& Longden, B. (2007) The first-year experience in higher education in the UK, HEA. Retrieved from: http://escalate.ac.uk/downloads/3365.pdf 